\title{
Comparative Evaluation of Swine Production with Other Domestic Livestock in Mbaitolu Local Government Area of Imo State, Nigeria
}

\author{
Alionye EB ${ }^{1}$, Ahaotu $\mathrm{EO}^{1 *}$ and Chukwu $\mathrm{AO}^{2}$ \\ ${ }^{1}$ Department of Animal Production Technology, Imo State Polytechnic Umuagwo, Nigeria \\ ${ }^{2}$ Department of Agricultural Economics and Extension, Imo State University Owerri, Nigeria \\ *Corresponding Author: Ahaotu EO, Department of Animal Production Technology, Imo State Polytechnic Umuagwo, Nigeria.
}

Received: September 20, 2019; Published: October 30, 2019

DOI: 10.31080/ASAG.2019.03.0703

\begin{abstract}
The researcher has undertaken this study on comparative evaluation of swine production with other domestic livestock in Mbaitolu Local Government Council of Imo State, Nigeria to proffer some solution to the problems hindering the rearing of swine in the study areas (Mbieri, Ogwa, Orodo, Ogbaku, Eziama - Obiato, Umunoha, Ifakala, Ubomiri and Afara). The researcher used descriptive survey design to carry out the study. The population for the study was 10,450 respondents drawn from nine towns of Mbaitolu Local Government Council. 600 respondents were proportionally and randomly selected as sample size for the study. General objective was formulated from which five specific objectives were formulated. Among these - is to compare swine prolificacy over the prolificacy of other domestic livestock. Five research questions were formulated to guide this study, among these is - what importance has the prolificacy of swine over other domestic livestocks like goats, sheep, horse and cattle? Five null hypotheses were formulated for the study among these is - there is no significant relationship between the prolificacy of swine over the prolificacy of other domestic livestock in Imo State. Pilot study was conducted at Umuagwo community using 20 respondents that reared domestic livestocks. This area was not part of the study location. Questionnaires were used as a medium for data collection. One sample T-test was used to test five null hypotheses at 0.05 level of significance and all the null hypotheses were rejected meaning that there were significant differences between pig productions over the production of other domestic livestock. The analysis yielded the following results: swine production was accepted to be more prolific than other domestic livestocks like goats, sheep, horse and cattle. It was also agreed that swine were more adapted to wide varieties of feeds which made them to grow more quickly than other domestic livestocks. It was concluded that swine production was more economically important than the rearing of other domestic livestock. It was recommended that National Poverty Eradication Programme (NAPEP) in Imo State should enlighten the respondents on the economic importance of swine production over the rearing of other domestic livestock. Piglets should be made available to farmers who wish to embark on swine production at affordable price by Anambra - Imo River Basin Development Authority (AMRBDA).
\end{abstract}

Keywords: Swine Production; Domestic Livestock; Mbaitolu Local Government Council

\section{Introduction}

Domestication of livestock started by the early hunters that go about in search of plants and animals for food. Adeleye and Falusi (1986) testified that some of these animals captured alive, especially the young ones were kept alive and reared for some times before killing them for food while some of them were kept to continue to produce young ones. This practice gave birth to the domestication of livestock that were in full practice today because of the economic importance attached to the animals and their byproducts. However, economic importance of pig production over other domestic livestock (like poultry, sheep, goats, horses, cattle, rabbits, etcetera) in areas like pigs prolificacy, efficiency of pigs conversion of feed to useful products (pork meat, skin, hair and manure), the advantages of dressing percentage with nutrients values and part of pig meat (insulin) used in treating diabetic patients, rearing systems (extensive, semi-intensive and intensive) and finally financial benefits in terms of market demand and sup- ply over other domestic livestock were so great. These have made it possible for pig production to become one of the lucrative business among other domestic livestock in some countries like - Europe, China, India, America, Cameroun, Ghana and other countries.

This business involved the use of improved breeds with good feeding and management practices which included disease and parasites control measures (Eusebio, 1980). However, in poorer countries like Africa, improvement in pig production was slow compared to the improvement in other domestic livestock production for example; many tropical African countries like Cameroun, Ghana, Togo, Nigeria and Zimbabwe large number of domesticated native pigs were raised as scavengers (extensive system) or raised as backyard (intensive system) to be depended on kitchen and farm wastes are still in practice.

In spite of the low levels of development, pig production continued to provide a significant amount of animal protein, energy, 
minerals, manure thereby improving the diet and social welfare of rural people. The productivity levels in terms of meat yield of cattle and pig differed from country to country. For example, pigs can yield 4-5 times more meat than cattle per tone of live weight. This ratio varied from country to country and region to region. This variation in the level of meat production of cattle and pigs may be as a result of the use of different breeds of pigs and the level of management practices which included disease and parasites control measures (Eusebio, 1980).

Rogers, (1990) explained that like other domesticated livestock, that have their origin from wild species, all domesticated breeds of pigs were believed to have originated from three major wild species: 1st - Sus vittatus and/or Sus indicus - the wild pigs of China, Japan and southeast Asia, 2nd breed was called sus scrofa - the wild pig of Europe which was believed to have originated from Asiatic Continent along with other domestic livestock like poultry, sheep, goats, cattle and other livestock that were brought by the early settlers. Edipega (2005) postulated that in 18th Century, Chinese pigs were introduced to Australia, Britain, Caribbean, America while pigs species domesticated in India was called Sus crist citus which was believed to have originated from Southeast Asia. The third breed of pigs found in Africa was called West African Dwarf - commonly found were the Bakosi of Cameroun and Ashanti of Ghana. Eusebio (1980) and Pond and Maner (1994) pointed out that the practice of improved breeds through selection and introduction as to produce high quality breeds of pigs resulted into multiple names of pigs found in the world today such as Berkshire, Chestwhite, Durco-Jersey, Hamshire, Landrace, large white, Poland, China, Tamworth et-cetera.

Today, all these different breeds of pigs can be found everywhere in Nigeria either through introduction and or selection through breeding practices carried out to boost pig production (Eusebio, 1980, Pond and Maner, 1994). Admorson (2000) gave example of the factors that might militate the rearing of pigs in a particular place to be religion and custom and belief of the people. Admorson cited an example of Northern part of Sudan as one of African countries that was largely dominated by Muslim community and pointed out that pig production cannot be possible there. Admorson (2000) pointed out other factors like scarcity of food (grains, root and tubers crops) and long dry season (drought) can be militating factors to the production of pig business.

Several factors such as religion, custom, belief and scarcity of feeds like grains, tubers and root crops were the militating factors preventing the pig production business in any particular area (Admorson, 2000). The researcher now wondered why pig production as a business cannot take place in Imo State (Mbaitolu Local Government Area) if these factors mentioned are not the militating factors to pig production in this zone. This has generated an inquisitive investigation on the side of the researcher that led the researcher to have an interactive discussion with some rural people from Mbaitolu Local Government Area.

The researcher later discovered that people of Mbaitolu Local Government Area refused to rear pigs not because of scarcity of feeds like grains, tuber and root crops but because of pigs abnormal habit like toiling children's graveyard and removing the buried bodies thereby re-wounding the healing minds of the parents concerned, lying down in a dirty environment and eating dirty feeds that have low nutrient values. Apart from these, pig meat (pork) was observed to contain only fat. Feeding and rearing of pig (extensive, semi intensive and intensive) were observed to be more costly and labour involving and the value of pigs was not related to our culture, finally pig have no position in the public markets like other domestic livestock (poultry, goats, sheep, cattle). In the process of carrying out these investigations, the following questions were put before the researcher by the rural people of Mbaitolu Local Government Area.

\section{Materials and Methods}

Research design

The researcher will use descriptive survey design in the face of large and disperses population in the study location like this. The design is chosen because of its usefulness in collecting primary data from the target population. This helped the researcher in establishing relationship between the variable that were used to generalize the research results on the entire population. In order to support the above points, Olayiwola (2007) said that it was an effective way of gathering data from different sources within the shortest possible time at relatively cheaper cost.

\section{Population for the study}

The population for this study comprised of 300 respondents that reared at least one or more domestic livestock in the nine (9) selected communities in Mbaitolu Local Government Area.

The breakdown of the population is stated in table 1 .

\begin{tabular}{|l|c|c|}
\hline $\begin{array}{c}\text { Randomly Selected } \\
\text { Communities }\end{array}$ & $\begin{array}{c}\text { Number of Target } \\
\text { Population }\end{array}$ & $\begin{array}{c}\text { Percentage } \\
\text { (\%) }\end{array}$ \\
\hline Mbieri & 45 & 15 \\
\hline Ogwa & 30 & 10 \\
\hline Orodo & 30 & 10 \\
\hline Ogbaku & 30 & 10 \\
\hline Eziama - Obiato & 45 & 15 \\
\hline Umunoha & 30 & 10 \\
\hline Ifakala & 30 & 10 \\
\hline Ubomiri & 30 & 10 \\
\hline Afara & 30 & 10 \\
\hline Total & 300 & 100 \\
\hline
\end{tabular}

Table 1.

Sample Size and Sampling Procedure

Manipulations of the whole subjects in educational research is not easy because of large scattered and distant of the population that may result into ambiguity. In order to reduce this ambiguity, random sampling was used. In view of this, Obe (2010) testified that if the representative is to be ensured, twenty percent should be drawn from the population of 1000 , ten percent from the population of 5000 and five percent from the population of 10,000 and above were recommended. 


\begin{tabular}{|l|c|c|c|}
\hline S/N & $\begin{array}{c}\text { Communities } \\
\text { Towns }\end{array}$ & Sample Size & $\begin{array}{c}\text { Percentage } \\
\text { (\%) }\end{array}$ \\
\hline 1 & Mbieri & 45 & 15 \\
\hline 2 & Ogwa & 30 & 10 \\
\hline 3 & Orodo & 30 & 10 \\
\hline 4 & Ogbaku & 30 & 10 \\
\hline 5 & Eziama - Obiato & 45 & 15 \\
\hline 6 & Umunoha & 30 & 10 \\
\hline 7 & Ifakala & 30 & 10 \\
\hline 8 & Ubomiri & 30 & 10 \\
\hline 9 & Afara & 30 & 10 \\
\hline Total & & 300 & 100 \\
\hline
\end{tabular}

Table 2: Sample Size for the Study.

Instrument for data collection

The researcher used questionnaire as well as oral interviews schedule as instruments for data collection. In the case of the oral interview schedule, the researcher used the same questionnaire on the illiterate respondents as an instrument for data collection. The questionnaire was divided into two sections. Section ' $A$ ' contained personal bio-data of the respondents such as names, age, gender, marital status, qualification; domestic animals reared other than swine and years of experience. The section B contained twenty five (25) questions (items) based on the research questions for example:

\section{Validity for the instrument}

The validity of the instruments in terms of content and face was determined by experts from the School of Agriculture and Agricultural Technology, Imo State Polytechnic Umuagwo. The experts examined the quality of these instruments with respect to the research questions, objectives and hypotheses. All critics and comments made by these experts were finally used to improve the quality of the measuring instruments.

\section{Pilot study}

After necessary correction and validation of the instruments, a Pilot study was conducted at Imo State Polytechnic Umuagwo Community with twenty (20) respondents that reared domestic livestock to test the reliability of the instruments. This town was not part of the study location but has equal characteristics with the study area.

\section{Reliability of the instrument}

The data collected from the pilot study were analysed using descriptive statistics (percentage and frequencies).

\section{Procedure for data collection}

The researcher selected one research assistant from each of the towns selected and gave them one day training on how to answer the questionnaire. The researcher sought for permission from the clan heads of each selected study area. The researcher keeps strictly to the right and privacy of the respondents. The literate respondents were requested to fill the questionnaire and return them within seven (7) days through the research assistants of each zone, while those that were illiterate, oral interview was conducted for them by the researcher using interview schedule with the same questions as contained in the questionnaire on the spot to avoid misinterpretation of the information.

\section{Procedure for data analysis}

The data collected were analyzed using frequencies, percentage and means to answer Research Questions.

\section{Results and Discussion}

Analysis of demographic variables of the respondents Analyses of data to answer research questions

Research Question One: Of what importance is the prolificacy of pig production over the rearing of other domestic livestock such as cattle, goats, sheep and rabbits?

The analysis of demographic variables are shown in Tables 3 to 9

Table 3 showed the distribution of the respondents by gender, it revealed that 178 representing $32.19 \%$ were males while 375 (67.81\%) were females. This indicated that there were more females that rear domestic livestock than men in Mbaitolu Local Government Council.

\begin{tabular}{|l|c|c|}
\hline \multicolumn{1}{|c|}{ Gender } & Frequency & Percentage \\
\hline Male & 178 & 32.19 \\
\hline Female & 375 & 67.81 \\
\hline Total & 553 & 100 \\
\hline
\end{tabular}

Table 3: Percentage distribution of Respondents by Gender.

Table 4 showed the distribution of respondents by marital status which revealed that $162(29.29 \%)$ were single while 391 $(70.71 \%)$ were married men and women. This figure showed that married men and women were highly engaged in the rearing of domestic livestock than those that were single as to reduce their family responsibilities.

\begin{tabular}{|l|c|c|}
\hline \multicolumn{1}{|c|}{ Marital status } & Frequency & Percentage \\
\hline Married & 391 & 70.71 \\
\hline Single & 162 & 29.29 \\
\hline Total & 553 & 100 \\
\hline
\end{tabular}

Table 4: Percentage Distribution of Respondents by Marital status.

Table 5 showed the distribution of the respondents by ages that rear the domestic livestock. The table revealed that 65 (11.75\%) were the respondents whose age was above 60 years, 103 (18.62\%) respondents were those whose ages were between 25-30 while the ages between 31-60 years were those respondents 385 (69.62\%) that were highly engaged in the rearing of domestic livestock. The table 5 showed that rearing as secondary occupation in Mbaitolu 
Local Government Council. started gradually from the ages of 2530 years with 103 respondents involved and grew very high as the respondents reached the age of 31-60, 385 (69.62\%) which was their active period but started to decline at above 60 years when the respondents were less active.

\begin{tabular}{|lcc|}
\hline Age (in years) & Frequency & Percentage \\
$25-30$ & 103 & 18.62 \\
$31-60$ & 385 & 69.62 \\
Above 60 & 65 & 11.75 \\
Total & 553 & 100 \\
\hline
\end{tabular}

Table 5: Percentage Distribution of Respondents by age at which domestic livestock were reared.

Table 6 showed that rearing of domestic livestock was very common with those respondents 267 (48.28\%) that were between illiterate to class six. The respondents with O'. level 191 (34.54\%) saw rearing as alternative to other business while above ' 0 ' level was very low with 95 (17.18\%). The high figure of about 267 (48.28\%) of the respondents was that, they saw rearing of these domestic livestock as the only alternative means of solving their immediate problems.

\begin{tabular}{|l|c|c|}
\hline \multicolumn{1}{|c|}{ Qualifications } & Frequency & Percentage \\
\hline Illiterate -class 6 & 267 & 48.28 \\
\hline O' level & 191 & 34.54 \\
\hline Above O. level & 95 & 17.18 \\
\hline Total & 553 & 100 \\
\hline
\end{tabular}

Table 6: Percentage Distribution of Respondents by level of qualification.

Table 7 revealed the domestic livestock reared based on likeness. It can be seen that 255 (64.19\%) respondents preferred to rear poultry to other domestic livestock. 211 (28.16\%) preferred to rear goats while $87(15.73 \%)$ respondents preferred to rear sheep. This has clearly shown that people in Mbaitolu Local Government Council preferred to rear poultry and goats to sheep because the value of sheep in their culture was not much compared to poultry and goats since Islam was not predominantly observed in the study area like other religions (Christianity and Traditional worship).

\begin{tabular}{|l|c|c|}
\hline \multicolumn{1}{|c|}{ Domestic livestock } & Frequency & Percentage \\
\hline Goats & 211 & 38.68 \\
\hline Sheep & 87 & 15.73 \\
\hline Poultry & 225 & 64.19 \\
\hline Total & 553 & 100 \\
\hline
\end{tabular}

Table 7: Percentage Distribution of Respondents by domestic livestock mostly preferred.

Table 8 revealed those domestic livestock that produced high and low quantity of meat. $21.88 \%$ revealed the respondents that agreed that goat meat was smaller than sheep and poultry. $17.54 \%$ revealed those respondents that agreed that sheep meat was smaller than goats and poultry, while 335 (60.58\%) respondents agreed that poultry meat was smaller than goats and sheep. The high fig- ure of respondents that agreed that poultry meat was the smallest was only done on mere observation of the animals without considering the amount of bones contained in these domestic livestockgoats, sheep and poultry.

\begin{tabular}{|l|c|c|}
\hline \multicolumn{1}{|c|}{ Domestic livestock } & Frequency & Percentage \\
\hline Goats & 121 & 21.88 \\
\hline Sheep & 97 & 17.54 \\
\hline Poultry & 335 & 60.58 \\
\hline Total & 553 & 100 \\
\hline
\end{tabular}

Table 8: Percentage Distribution of respondents by domestic livestock that produced less meat.

Table 9 revealed that method adapted by the respondents in rearing domestic livestock in Mbaitolu Local Government Council 412 (74.51\%) respondents adapted extensive system of rearing of their domestic livestock while, 141 (25.49\%) practiced intensive system of rearing domestic livestock. The high figure of 412 (74.51\%) showed that extensive system of rearing domestic livestock in Mbaitolu Local Government Council was a common and accepted practice adapted by the respondents in rearing their livestock. This was because the respondents agreed to be the cheapest means of rearing domestic livestock.

\begin{tabular}{|l|c|c|}
\hline Method adapted & Frequency & Percentage \\
\hline Extensive rearing & 412 & 74.51 \\
\hline Intensive rearing & 141 & 24.49 \\
\hline Total & 553 & 100 \\
\hline
\end{tabular}

Table 9: Percentage Distribution of the respondents by methods adapted in rearing domestic livestock.

A total of six hundred (600) copies of questionnaire were administered but five hundred and fifty three (553) were returned. Forty seven (47) questionnaires were not returned. The percentage of the returned questionnaire was $92.13 \%$ which was high enough to carry out the analysis.

The findings of responses to the research question one is presented in table 10 .

From Table 10, item one gave a means score of 3.36 which indicated that majority 495 representing $89.51 \%$ of respondents agreed that pigs were capable of farrowing twice a year based on their gestational period, as against 58 (10.49\%) that 'disagreed'. 477 (86.26\%) of the respondents agreed to item two which stated that pigs can farrow 8-10 piglets at a time and can wean 18-20 piglets in a year compared to other domestic livestock as against 76 (13.74\%) that 'disagreed'. This was supported with a means score of 3.29. Item three had a mean score of 2.32 which indicated that 227 (41.05\%) of the respondents agreed that goats/cow can kid/ calf twice in a year while majority 326 (58.95\%) of the respondents disagreed.

Item four had a means score of 2.46 which indicated that majority $290(52.44 \%)$ of the respondents disagreed that goats/sheep/ cattle will mature 7-8 months based on their gestational period, 


\begin{tabular}{|l|l|c|c|c|c|c|c|}
\hline S/N & \multicolumn{1}{|c|}{ Item Statement } & Agreed F & \% & Disagreed F & \% & Mean Score & Remarks \\
\hline 1. & $\begin{array}{l}\text { Pigs are capable of farrowing twice a year } \\
\text { based on their gestational period }\end{array}$ & 495 & 89.51 & 58 & 10.49 & 3.36 & Agreed \\
\hline 2. & $\begin{array}{l}\text { Pigs can farrow 8-10 piglets at a time and } \\
\text { wean 18-20 piglets in a year compared to } \\
\text { other domestic livestock }\end{array}$ & 4.77 & 86.26 & 76 & 13.74 & 3.29 & Agreed \\
\hline 3. & Goats/cow can kid/calf twice in a year & 227 & 41.05 & 326 & 58.95 & 2.32 & Disagreed \\
\hline 4. & $\begin{array}{l}\text { Goats/sheep/cattle will mature seven to } \\
\text { eight months based on their gestation } \\
\text { period }\end{array}$ & 263 & 47.56 & 290 & 52.44 & 2.46 & Disagreed \\
\hline 5. & $\begin{array}{l}\text { It takes goats, sheep and cattle 4-8 weeks } \\
\text { to wean their young ones }\end{array}$ & 133 & 24.05 & 420 & 75.95 & 1.95 & Disagreed \\
\hline & Aggregate mean score & & & & 2.67 & Agreed \\
\hline
\end{tabular}

Table 10: Opinions of Respondents on the prolificacy of pig production over the rearing of other domestic livestock.

while 263 (47.56\%) of the respondents agreed. Item five which stated that it took goats, sheep and cattle 4-8 weeks to wean their young ones. This tem had a mean score of 1.95 which showed that majority 420 representing $75.95 \%$ of the respondents disagreed as against only $133(24.05 \%)$ of the respondents that agreed.

On the overall, Table $10 \mathrm{had}$ an aggregate mean score of 2.67 which indicated that the respondents agreed that prolificacy of pig production was of importance over the rearing of other domestic livestock such as cattle, goats, sheep and horse.

Research Question Two: What are the major products acquired from pigs after feeding them with varieties of feeds?

The findings of responses to the research question two is presented in table 11 .

\begin{tabular}{|l|l|c|c|c|c|c|c|}
\hline $\mathbf{S / N}$ & \multicolumn{1}{|c|}{ Item Statement } & Agreed F & $\mathbf{\%}$ & Disagreed F & \% & Mean Score & Remarks \\
\hline 6. & $\begin{array}{l}\text { Swine can eat all types of feeds better than } \\
\text { other domestic livestock }\end{array}$ & 349 & 63.11 & 204 & 36.89 & 2.77 & Agreed \\
\hline 7. & $\begin{array}{l}\text { Based on adaptation to varieties of feeds, } \\
\text { pigs grow more quickly than sheep, goats, } \\
\text { cattle and horse }\end{array}$ & 558 & 95.48 & 25 & 4.52 & 3.49 & Agreed \\
\hline 8. & $\begin{array}{l}\text { Ladies shiny foot wears and bags, rugs and } \\
\text { brushes are made from swine skin and hair } \\
\text { respectively. }\end{array}$ & 182 & 32.91 & 371 & 67.09 & 2.14 & Disagreed \\
\hline 9. & $\begin{array}{l}\text { Swine manure enhance fish production } \\
\text { when it is properly handled }\end{array}$ & 241 & 43.58 & 312 & 56.42 & 2.37 & Disagreed \\
\hline 10. & $\begin{array}{l}\text { Pigs manure can be applied to soil to en- } \\
\text { hance crop production }\end{array}$ & 313 & 56.60 & 240 & 43.40 & 2.65 & Agreed \\
\hline & Aggregate mean score & & & & 2.68 & Agreed \\
\hline
\end{tabular}

Table 11: Opinions of Respondents on the major products acquired from pigs after feeding them with varieties of feeds.

From Table 11, majority of the respondents 349 (63.11\%) agreed with item six which stated that swine can eat all types of feeds better than other domestic livestock as against 204 (36.89\%) of the respondents that disagreed. The item had a mean score of 2.77. Item seven had a mean score of 3.49 which indicated more respondents 528 representing $95.48 \%$ agreed that pigs grow more quickly than sheep, goats, cattle and horse based on the adaptation to varieties of feeds compared with only 25 (4.52\%) of the respondents who disagreed. More respondents 371 (67.09\%) disagreed with the notion in item 8 that ladies shiny foot wear and hand bags were made from the skin, while rugs and brushes are made from swine hair compared with 182 (32.91\%) of the respondents that agreed. In line with these differences, item eight had a mean score of 2.14. Item 9 of Table 11 had a means score of 2.37 which revealed that 241 (43.58\%) of the respondents agreed that swine manure enhance fish production when it is properly handled as against $312(56.42 \%)$ of the respondents that dis- agreed. In item ten has 313 (56.60\%) of the respondents agreed that pigs manure can be applied to soil to enhance crop production as against 240 representing $43.40 \%$ that disagreed. Based on the number that agreed, the item had a means score of 2.65 .

On overall, Table 11 had an aggregate mean score of 2.68 which indicated that majority (63.11\%) of the respondents agreed that swine can eat varieties of feeds and grow more quickly than other domestic livestock like goats, sheep, cattle and horses. While majority of the respondents (56.42\%) disagreed that manure cannot enhance fish production and that ladies shiny footwear, hand bags, brushes and rugs cannot be made from swine skin and hair.

Research Question three: To what extent is the dressing percentage of pig meat with nutrient values and pig insulin more important than other domestic livestock? The findings of responses to the research question three is presented in table 12 . 


\begin{tabular}{|l|l|c|c|c|c|c|c|}
\hline S/N & \multicolumn{1}{|c|}{ Item Statement } & Agreed F & \% & Disagreed F & \% & Mean Score & Remarks \\
\hline 11. & $\begin{array}{l}\text { Matured pigs produced more meat than } \\
\text { other domestic livestock like poultry, } \\
\text { cattle, horse, goats, sheep, rabbit and } \\
\text { poultry }\end{array}$ & 387 & 69.98 & 166 & 30.02 & 2.94 & Agreed \\
\hline 12. & $\begin{array}{l}\text { Pig meat contains nutrient value like } \\
\text { meats of other domestic livestock like } \\
\text { cattle, goat and sheep }\end{array}$ & 175 & 31.65 & 378 & 68.35 & 2.18 & Disagreed \\
\hline 13. & $\begin{array}{l}\text { Pig production is the quickest means of } \\
\text { bridging } \\
\text { the gap between protein, energy and } \\
\text { mineral deficiency like other domestic } \\
\text { livestock }\end{array}$ & 154 & 27.85 & 399 & 72.15 & 2.13 & Disagreed \\
\hline 14. & $\begin{array}{l}\text { Among the domestic livestock, only pigs } \\
\text { insulin } \\
\text { can be used to treat diabetic patients }\end{array}$ & 423 & 76.49 & 130 & 23.51 & 3.06 & Agreed \\
\hline 15. & $\begin{array}{l}\text { Domestic livestock like cattle, goats, sheep, } \\
\text { poultry }\end{array}$ & 180 & 32.55 & 373 & 67.45 & 2.21 & Disagreed \\
\hline $\begin{array}{l}\text { and rabbit insulin will be used to treat } \\
\text { diabetes }\end{array}$ & & & & & & & \\
\hline Aggregate mean score & & & & & & & \\
\hline
\end{tabular}

Table 12: Opinions of Respondents on the importance of dressing percentage with nutrient values and part of pig meat (insulin) used in treating diabetes over other domestic livestock.

From Table 12, respondents agreed that matured pigs produced more meat than other domestic livestock like cattle, horse, goats, sheep, rabbit and poultry. The mean score of the respondents on item 11 was 2.94 which indicated that 387 (69.98\%) agreed as against $166(30.02 \%)$ that disagreed. Item 12 had a mean score 2.18 which indicated that only 175 (31.65\%) of the respondents agreed that pig meat contains nutrient values like the meats of other domestic livestock like cattle, goats and sheep as against $378(68.35 \%)$ that disagreed. Only $154(23.51 \%)$ of the respondents agreed to the notion that pig production could be used as the quickest means of bridging the gap between protein, energy and mineral deficiencies like other domestic livestocks (item 13) as against $399(72.15 \%)$ of the respondents that disagreed. This indicated that more respondents disagreed therefore; the item had a mean score of 2.13. Item 14 had a mean score of 3.06 which indicated that more respondents 423 (76.49\%) agreed that among the domestic livestocks, only pig insulin can be used to treat diabetic patients compared with 130 (23.51\%) who disagreed. Item 15 had a means score of 2.21 which indicated that majority 373 (67.45\%) of the respondents disagreed to the notion that domestic livestock like cattle, goats, sheep, poultry and rabbit insulin were also used to treat diabetes as against $180\left(32.55 \%{ }^{\wedge}\right)$ of the respondents that agreed.

On the overall, Table 12 had an aggregate mean score of 2.50 which indicated that more respondents agreed that mature pig produce more meat than poultry, goats, sheep, rabbits, horse and cattle. Majority also agreed that pig insulin can be used to treat diabetic patient. However, majority of the respondents (68.35\%) disagreed with notion that pig meat contained nutrients like protein, energy and mineral like other domestic livestocks and they also disagreed with the saying that swine production was the quickest means of bridging the gap between protein deficiencies like other domestic livestocks.

Research Question Four: To what extent is the rearing system of pig easier and cheaper than the rearing of other domestic animals? The findings of responses to the research question four is presented in table 13.

From table 13, only 371 (67.09\%) of the respondents agreed that people of People of Mbaitolu Local Government Council prefer to rear other domestic livestocks to swine (Item 16) as against 182 representing $32.91 \%$ of the respondents that disagreed. The item had a mean score of 2.87. Item 17 sought to find out whether goat, sheep and cattle requires more hectare of natural land to rear than swine. In response to this item, 486 representing $87.88 \%$ agreed as against $67(12.12 \%)$ of the respondent that disagreed. The item had a mean score of 3.33. Item 18 of the table had a mean score of 1.76 which indicated that respondents $90(16.27 \%)$ agreed that production of pig can be hindered in People of Mbaitolu Local Government Council by factors like long dry season, religious beliefs and others as against 463 (83.73\%) of the respondents that disagreed.

The majority $(83.73 \%)$ of the respondents disagreed with the idea that swine production in People of Mbaitolu Local Government Council was hindered by Muslim community, long dry season, lack of feeds, religious belief and custom. Majority 390 (70.52\%) of the respondents agreed that swine production in People of Mbaitolu Local Government Council was hindered by abnormal behavior of swine like toiling children grave yard, removing the buried bodies thereby re-wounding the healing minds of the affected parents, lying down in a dirty environment and eating dirty feeds that have low nutrient value, while only 163 (29.48\%) of the respondents disagreed with the item. The item had a mean score of 2.93. Item 


\begin{tabular}{|l|l|c|c|c|c|c|c|}
\hline S/N & \multicolumn{1}{|c|}{ Item Statement } & Agreed F & \% & Disagreed F & \% & Mean Score & Remarks \\
\hline 16. & $\begin{array}{l}\text { People of Mbaitolu Local Government } \\
\text { Council prefer to rear poultry, sheep, goats } \\
\text { and cattle to swine }\end{array}$ & 371 & 67.09 & 182 & 32.91 & 2.86 & Agreed \\
\hline 17. & $\begin{array}{l}\text { Goats, sheep and cattle require more hect- } \\
\text { are of natural land to rear than swine }\end{array}$ & 486 & 87.88 & 67 & 12.12 & 3.33 & Agreed \\
\hline 18. & $\begin{array}{l}\text { Production of pig in People of Mbaitolu } \\
\text { Local Government Council can be hin- } \\
\text { dered by any of the following factors: area } \\
\text { occupied by Muslim Community, long } \\
\text { dry season (drought), scarcity of feed, } \\
\text { religious belief }\end{array}$ & 90 & 16.27 & 463 & 83.73 & 1.76 & Disagreed \\
\hline 19. & $\begin{array}{l}\text { Pig production in People of Mbaitolu Local } \\
\text { Government Council is hindered because } \\
\text { of abnormal behavior of pigs }\end{array}$ & 390 & 70.52 & 163 & 29.48 & 2.93 & Agreed \\
\hline 20. & $\begin{array}{l}\text { It is cheaper to construct pig pen than } \\
\text { poultry, goats and sheep pens }\end{array}$ & 518 & 93.67 & 35 & 6.33 & 3.45 & Agreed \\
\hline & Aggregate mean score & & & & 2.87 & Agreed \\
\hline
\end{tabular}

Table 13: Opinions of Respondents on the extent to which the rearing system pig is easier and cheaper than the rearing of other domestic livestock.

twenty had a means score of 3.45 which indicated that more respondents 518 (93.67\%) agreed that it is easier and cheaper to construct swine pen than poultry, goats, sheep and rabbit as compared with just $35(6.33 \%)$ of the respondents that disagreed to the item. On the overall, Table $13 \mathrm{had}$ an aggregate mean score of 2.87 which signified that more respondents agreed that it is easier and cheaper to rear pig than other domestic livestocks in term of land requirement for grazing and construction of domestic livestock housing and feeding.
Research Question Five: To what extent is pig production more financially rewarding and profitable to farmers than other domestic livestocks such as cattle, goat, sheep and poultry in terms of market demand and supply?

The findings of responses to the research question five is presented in table 14.

\begin{tabular}{|c|c|c|c|c|c|c|c|}
\hline $\mathrm{S} / \mathrm{N}$ & Item Statement & Agreed F & $\%$ & Disagreed F & $\%$ & Mean Score & Remarks \\
\hline 21. & $\begin{array}{l}\text { Pigs cannot be found in every market unlike } \\
\text { goat, sheep and poultry }\end{array}$ & 336 & 60.76 & 217 & 39.24 & 2.72 & Agreed \\
\hline 24. & $\begin{array}{l}\text { The demand for pig meat (pork) is higher } \\
\text { than the demand for other domestic animals }\end{array}$ & 50 & 9.06 & 503 & 90.96 & 3.39 & Disagreed \\
\hline 25. & $\begin{array}{l}\text { More money is spent in preserving pig meat } \\
\text { (pork) than the meat of goats, sheep and } \\
\text { cow }\end{array}$ & 243 & 42.31 & 319 & 57.69 & 2.34 & Disagreed \\
\hline
\end{tabular}

Table 14: Opinions of Respondents on the profitability of pig over other domestic livestock.

From table 14, item 21 had a mean score of 2.72 which indicated that more respondents $336(60.76 \%)$ agreed that pig cannot be found in every market unlike goat, sheep and poultry as compared with 217 (39.24\%) of the respondents who disagreed to this notion. Item 22 had a mean score of 3.14 which also indicated that more respondents 443 representing $80.11 \%$ agreed that it is very difficult and costly to get pig meat everyday as compared with goat, sheep and poultry meat as compared with 110 (19.89\%) of the respondents that disagreed to the notion. Item 23 of table showed that $460(83.18 \%)$ of the respondents agreed that it is easy to sell 8-10 piglets every year than selling 4-6 kids, lamb and calves as against $93(16.93 \%)$ of the respondents that disagreed.
The item had a mean score of 3.23 to support this notion. Item 24 had a mean score of 3.39 which indicated that 503 representing $90.96 \%$ disagreed that demand for pork is higher than the demand for the meat of other domestic livestocks while only $50(9.04 \%)$ of the respondents agreed with the notion. Item 25 of the table had a mean of 2.34 which indicated that $243(42.31 \%)$ respondents agreed that more money is spend in preserving pork than the meat of goat, poultry, rabbit sheep and cow as against 319 (57.69\%) respondents that disagreed with the notion.

On the overall, Table 14 had an aggregate mean score of 2.96 which indicated that more respondents agreed that swine produc- 
tion is more financially rewarding and profitable to farmers than other domestic livestocks such as cattle, goats, sheep, poultry in terms of market demand and supply since swine (pork meat) cannot be seen in every market day. The idea that a sow can farrow 8-10 piglets at a time and can farrow twice a year and wean 1820 piglets in a year is a clear testimony of how swine production is financially beneficial and profitable more than other domestic livestock. A swine farmer can sell 8-10 piglets in a year compared to other domestic livestocks like sheep that lamb 1-2 at a time and can lamb twice in a year base on its gestational period while goats can kid 1-3 at a time and can only kid once a year, cattle can calf one calf at a time and only once in a year.

Preservation of meat in the meat industries in Nigeria is a problem today subjecting many meat dealers to huge loss of capital. This was not common to swine (pork meat) because of its nonavailability in every market day. This made the demand to be more by the consumer than the supply within that sport thereby reducing the cost of preservation when compared with other domestic livestock.

Pigs are capable of converting varieties of feeds consumed to useful products (pork, hair, skin and manure) unlike other domestic livestock, and have the advantage of growing more quickly than other domestic livestock. Matured pig produces more meat than other matured domestic livestock. Pig insulin was used to treat a disease called diabetes and finally, pork contains not only fat, but protein and minerals. Rearing system of pig production was easier and cheaper than the rearing system of other domestic livestock in terms of land requirements for grazing, feeding and construction of housing since pigs are capable of eating varieties of food that have low nutrient values and their housing can be constructed with tree trunks and thatch grass.

Pigs are more financially rewarding than other domestic livestock since one sow was capable of farrowing 8-10 piglets at a time and can farrow twice and weaned 18-20 piglets in a year, meaning that pig farmer can sell 8-10 piglets in a year compared to other domestic livestock such as goats, sheep, cattle and horse farmers that cannot sell 4-6 kids, ram, and calves respectively in a year. Finally, the fact that pigs cannot be found in the public market like other domestic livestock made its demand to be more than the supply by its consumers which was an indication of pig production to be more financially rewarding than other domestic livestocks.

\section{Discussion and Major Findings}

The result obtained for the study revealed that respondents agreed to items in Table 11 which revealed that pigs were more prolific than other domestic livestocks like goats, sheep, horse and cattle. Respondents agreed with a mean score of 3.36 that pigs farrowed more frequently than other domestic livestocks. These findings was in line with Eusebio (1980) who inferred that swine can farrow 8-10 piglets at a time and can farrow twice in a year and wean 18-20 piglets based in their gestational period of 112-120 days, while other domestic livestocks had longer gestation period. For example, cattle have a gestation period of about 270-290 days which also depended on the species. It was also found that pig were capable of producing more off springs than other domestic livestock.

Eusebio (1980), observed in line with this that a matured sow was capable of producing 8-10 piglets at one farrowing period, while according to Oyenuga (1999), cattle were capable of producing only one calf per year. Another finding of this study was that swine were capable of eating wide varieties of feeds and converting them to useful products like skin, hair and manure for example, lady shiny footwear and handbags were made from the skin of swine while rugs and brushes were made from swine hair and that manure derived from pig enhanced fish production.

This finding was in line with Edward (1998) who stated that pig production have quicker and better means of converting feeds consumed to meat, skin, hair, manure than cattle, goats and sheep when they were provided with high quality feeds with the exception of rice bran and hay. Buttressing this view Sandra (2006), pointed that pigs had speedy mechanism in the conversion of feeds to meatfor human consumption compared to other domestic livestock. The respondents agreed with a mean score of 2.77 that pigs adapt to varieties of feed and as such they grow more quickly than other domestic livestocks. In agreement with this view, Hughs (1998), opined that unlike cattle, sheep and goats, pigs can feed on mouldy grains or other grains that have been damaged by other livestocks in the processing of feeds.

The study also found that the dressing percentage and pig insulin is more important than that of other domestic livestock in the treatment of diabetic patients. The respondents disagreed with a mean score of 2.40 that pig meat contains some nutrient values like the meat of other domestic livestocks like poultry, rabbit, horse, cattle, goat and sheep. However, the finding of dressing percentage was supported by Eusebio (1980), who found out that the dressing percentage of pig (Hog 70-90\%) was higher than the other domestic animals. Pigs have $76.6 \%$ while others like poultry $64.3 \%$, cattle $52.2 \%$ horse $49.1 \%$, rabbits $48.1 \%$ and goats $44.1 \%$. Lois (1995), gave reasons why goat's figure was very low because of being bonny due to eating all sorts of things like leather, clothes, wood and shoes, that may or may be low in food value.

On the other hand, Oyenuga (1999), in his findings highlighted the reason why cattle figure was low due to consumption of high quality hay, silage and pasture as to stimulate rumen bacteria that will make fermentation to take place easily for future milk production. Apart from future milk production, hay, silage and pasture enhance early rumen development. Hammerman., et al. (2010), stated that rats could not produce any insulin on their own due to higher glucose level. The authors used pancreatic cell of immature pigs by transplanting on the 10 rats. As the immature pancreatic cell developed, the rats began to produce insulin that helped to lower their blood glucose level but was not at normal level. Later one rat was treated with islet cell from the adult pig while the nine (9) rats were used as control group. After 12 weeks and several months, the result showed that one rat treated separately had normal blood glucose level while the nine (9) rats that were put as control group continued to produce high blood glucose. This showed that pig insulin was very good in controlling diabetes. 
The study also found out that the rearing system of pig was easy and cheaper compared to that of other domestic livestocks like cattle, goats and sheep. Respondents agreed with a mean score of $3.33(87.88 \%)$ against the rearing of other domestic livestock that requires more hectare of land. This finding agreed with Eusebio (1980) who stated that pigs require small area or space in which to grow. The author said that pigs can be raised in a small area either in a closed confinement within a building or a small area of pasture unlike cattle, sheep and goats that usually required one hectare of natural pastures per head. Also Lois (1995), clarified that in rearing pigs; plastic materials that were strong enough to withstand pigs was not suitable to goats because goats were active creatures that appeared to think that speed of entry to their pens was necessary at all times.

Wilfred (1999) said that goats' behavior made them to jump and explore their surroundings. The author viewed goats as inquisitive animals that did not want confinement like other domestic livestocks. In supporting the behavior of goats, Jennse (1998), described goats as destructive to trees, gardens and crops. The author described goats as notorious animals in a cultivated land and when confined to yard, they tried to trespass on privacy and liberty by refusing to be silent out of her own company. The author pointed out that this negative behavior resulted into solution found on their neck as tethering chain. The study found that pig was more financially rewarding than other domestic livestock. This was because pigs grow quickly and also produce more piglets than other domestic livestock. This finding coincides with Jean (1992), who pointed out that the demand for the consumption of pork was very high in areas where traditions do not interfere with it.

In addition, the study also found that there was significant differences between the economic importance of swine production and production of other domestic livestock on variable like prolificacy, efficiency of feed conversion, dressing percentage of meat and insulin used in treating diabetic patients, rearing system and financial benefit. In conclusion, when all findings are compared, swine have greater economic importance over other domestic livestocks like poultry, rabbits, goats, sheep, horse and cattle [1-37].

\section{Conclusion}

Based on the findings of this study, it was concluded that pigs have economic importance more than other domestic livestocks since one sow can farrow 8-10 piglets at a time and can farrow twice and wean 18-20 piglets in a year based on their gestational period of 112-120 days compared to sheep that can lamb 1-2 rams at a time and can lamb twice in a year based on their gestational period of 147 days, while goats can kid 1-3 at a time and can kid once in a year based on the gestational period of 150 days and on the other hand, cattle can calf one calf at a time and can calf once in a year based on their gestational period of 273-288 days.

Pigs can wean the young ones within 4-5 weeks and they matured within 7 months. On the other hand, sheep matured within 10 months, while goats matured within one year and finally cattle wean their young ones within 300 days and matured within three to four years. Pigs are capable of eating varieties of feeds and convert them to useful products like pork, skin, hair and manure. This made them to grow more quickly than other domestic livestocks. Example ladies shiny foot wears and handbags can be made from the skin of pigs while pig hair was used in making rugs and brushes, despite the fact that pigs eat dirty feeds that have low nutrient values. Finally, pig manure was used to enhance fish and crop production.

Matured pigs produced more meat than the meats of other matured domestic livestock. Pig meat also contained protein and minerals apart from fats. Part of pig meat insulin was used in controlling disease called diabetes. Rearing system of pig production was easier and cheaper in terms of feeding and land requirement for grazing since pigs are capable of eating varieties of feeds thereby reducing the cost of feeding. Construction of pig housing can be made of tree trunks with thatch grass compared to housing of other domestic livestock that cannot be made from tree trunks with thatched grass.

Studies also reviewed that based on the number of offspring farrowed at a time and number of times one sow can farrow and number of weaned piglets in a year enable the pig farmer to sell 8-10 piglets in a year compared to goats, sheep and cattle farmers that cannot sell 4-6 kids, rams and calves respectively in a year. The fact that pig were not found in public market and its meat were not found everyday like other domestic livestock made their demand to be higher than supply by the consumers of pig meat thereby resulting into instability of the price.

\section{Bibliography}

1. Adejoba OR., et al. "Participation, prospects and problems of piggery Business in selected local government areas in Ibadan Metropolis". Tropical Animal Health and Production 7 (2004): 155-159.

2. Ajala MK. "Economics of swine production in Ajama's local government area of Kaduna state, Nigeria". Tropical Journal of Animal Science 6 (2003): 53-62.

3. Agunbiade JA., et al. "An assessment of pig production systems". Ogun Journal of Agricultural Sciences 1 (2001): 108115.

4. Bamiyi H. "Factors militating against animal production in Nigeria". International Journal of Livestock Research 3 (2013): 54-66.

5. Berihu M., et al. "Health Management and Factors Affecting Small Scale Intensive Pig Production in East Shewa of Central Ethiopia". Advances in Biological Research 9 (2015): 373-380.

6. Berihu M and B Tamir. "Socio-economic and Farm Characteristics of Small Scale Intensive Pig Production in East Shewa of Central Oromia, Ethiopia”. World Applied Sciences Journal 33 (2015a): 1827-1833.

7. Berihu M and B Tamir. "Characterization of Feed Resources and Body Condition Scores of Pigs under Small Scale Intensive Production in East Shewa, Ethiopia". Academic Journal of $\mathrm{Nu}$ trition 4 (2015b): 106-112. 
8. Boe K. "Maternal behaviour of lactating sows in a loose housing system". Applied Animal Behaviour Science 35 (1993): 327338.

9. Bonde M., et al. "Indicators for the assessment of animal welfare in a sow herd with loose housed dry sows". Paper presented at the 51th Annual Meeting of the European Association for Animal Production (2000): 8.

10. Brouns F., et al. "Influence of fibrous feed ingredients on voluntary intake of dry sows". Animal Feed Science and Technology 54 (1995): 301-313.

11. Ezeibe $\mathrm{ABC}$. "Profitability analysis of pig production under intensive management systems in Nsukka Local Government Area of Enugu State, Nigeria". International Journal of Economic Development Research and Investment 1 (2010): 1-7.

12. Fasina FO., et al. "Cost Implications of African Swine Fever in Smallholder Farrow-to- Finish Units: Economic Benefits of Disease Prevention Through Biosecurity". Transboundary and emerging diseases 59 (2011): 244-255.

13. Fernandez A., et al. "Inbreeding effects on the parameters of the growth function in three strains of Iberian pigs". Journal of Animal Science 80 (2002): 2267-2275.

14. Gourdine JL., et al. "Effects of breed and season on performance of lactating sows in a tropical humid climate". Journal of Animal Science 84 (2006): 360-369.

15. Higgins M and Edwards SA. "The effects on welfare and production of using individual or group paddocks for farrowing sows and litters in an outdoor system". In: Livestock Farming Systems - more than food production (ed. J T Sorensen). EAAP Publication no 89, Wageningen Pers, Wageningen (1997): 273-276.

16. Kagira JM., et al. "Characteristics of the smallholder free-range pig production system in western Kenya". Tropical Animal Health and Production 42 (2010): 865-873.

17. Kambashi B., et al. "Smallholder pig production systems along a periurban-rural gradient in the Western provinces of the Democratic Republic of the Congo". Journal of Agriculture and Rural Development in the Tropics and Subtropics 115 (2014): 9-22.

18. Karlsson A., et al. "Muscle histochemical and biochemical properties in relation to meat quality during selection for increased lean tissue growth rate in pigs". Journal of Animal Science 71 (1993): 930-938.

19. Katongole CB., et al. "Strategies for coping with feed scarcity among urban and peri-urban livestock farmers in ampala, Uganda". Journal of Agriculture and Rural Development in the Tropics and Subtropics 113 (2012): 165-174.

20. Kumaresan A., et al. "Integrated resource-driven pig production systems in a mountainous area of Northeast India: production practices and pig performance". Tropical Animal Health and Production 41 (2009): 1187-1196.
21. Lanada EB., et al. "A longitudinal study of sows and boars raised by smallholder farmers in the Philippines". Preventive Veterinary Medicine 70 (2005): 95-113.

22. Lekule FP and Kyvsgaard NC. "Improving pig husbandry in tropical resource-poor communities and its potential to reduce risk of porcine cysticercosis". Acta Trop 87 (2003): 111117.

23. Lemke U., et al. "Evaluation of smallholder pig production systems in North Vietnam: Pig production management and pig performances". Livestock Science 105 (2006): 229-243.

24. Lemke U., et al. "Evaluation of biological and economic efficiency of smallholder pig production systems in North Vietnam". Tropical Animal Health Production 39 (2007): 237-254.

25. Moanaro Ngullie E., et al. "Traditional Animal Husbandry Practices in Tribal States of Eastern Himalaya, India: A Case Study". Indian Journal of Animal Nutrition 28 (2011): 23-28.

26. Mutua F., et al. "Farmer perceptions on indigenous pig farming in Kakamega District, Western Kenya". Nordic Journal of African Studies 19 (2010): 43-57.

27. Nath BG., et al. "Characterization of smallholder pig production system: productive and reproductive performances of local and crossbred pigs in Sikkim Himalayan region". Tropical Animal Health and Production 45 (2013): 1513-1518.

28. Nsoso SJ., et al. "Monitoring production, health and marketing of indigenous Tswana pigs in Ramotswa village of Botswana". Livestock Research for Rural Development 18 (2016): 125.

29. Oguniyi LT and Omoteso O.A "Economic analysis of swine production in Nigeria: A case study of Ibadan zone of Oyo State". Journal of Human Ecology 35 (2011): 137-142.

30. Patr MK., et al. "Problems and Prospects of Traditional Pig Farming for Tribal Livelihood in Nagaland". Indian Research Journal of Extension Education 14 (2014): 6-11.

31. Sinclair A., et al. "Evaluation of maternal and piglet influences on behaviour and production of Meishan synthetic and European White breeds of pig during lactation". Animal Science 66 (1998): 449-455.

32. Tummaruk P., et al. "Effect of birth litter size, birth parity number, growth rate, backfat thickness and age at first mating of gilts on their reproductive performance as sows". Animal Reproduction Science 66 (2001): 225-237.

33. Vaarst M., et al. "Animal health and welfare aspects of organic pig production". Proceedings: 13th International IFOAM Scientific Conference, Basel (2000): 373.

34. Van der Fels-Klerx HJ., et al. "Risk factors for bovine respiratory diseases in dairy young stock in the Netherlands: The perception of experts". Livestock Production Science 66 (2000): 35-46. 
35. Vermeer HM., et al. "Monitoring organic pig farms in The Netherlands". Proc. of the 51st annual meeting of the European Association of Animal Production, The Hague, The Netherlands (2000).

36. Warris PD., et al. "The thickness and quality of back fat in various pig breeds and their relationship to intramuscular fat and the setting of joints from the carcass". Meat Science 28 (1990): 21-29.

37. Wattanakul W., et al. "Performance and behaviour of lactating sows and piglets in crate and multi-suckling systems: a study involving European White and Manor Meishan genotypes". Animal Science 64 (1997): 339-349.

Volume 3 Issue 11 November 2019

(C) All rights are reserved by Ahaotu EO., et al. 